\title{
1. Introduction: the ILA Study Group on the role of soft law instruments in international investment law ${ }^{1}$
}

\author{
Andrea K. Bjorklund and August Reinisch
}

The Study Group was established by the International Law Association (ILA) Executive Council in November 2008 for a three-year period with the express mandate "to study the development of soft law instruments in international investment law and the feasibility of a "codification" of the present state of this field of international economic law'.

The Executive Council appointed Sir Franklin Berman (UK ILA Branch) as Chairman, as well as Andrea K Bjorklund (US ILA Branch) and August Reinisch (Austrian ILA Branch) as Co-Rapporteurs of the Study Group. As of Spring 2010, further members of the Group were Yas Banifatemi (French ILA Branch), Giuditta Cordero-Moss (Norwegian ILA Branch), Melaku Desta (UK ILA Branch), Moshe Hirsch (Israeli ILA Branch), Daniel Magraw (US ILA Branch), Kate Miles (Australian ILA Branch), Audley Sheppard (UK ILA Branch), Christian Tietje (German ILA Branch), Matthew Weiniger (UK ILA Branch), Catherine Yannaca-Small (Greek ILA Branch), Andreas Ziegler (Swiss ILA Branch).

The establishment of the Study Group was initiated by a proposal elaborated jointly by Thomas Wälde (deceased, formerly UK ILA Branch) and August Reinisch after the ILA Committee on the International Law on Foreign Investment had come to an end at the Rio Conference in 2008. It had concluded its work with the publication of the Oxford Handbook on International Investment Law, ${ }^{2}$ which addressed major issues of both substantive and procedural investment law. In the 
course of that Committee's work it had become evident that the growing arbitral case law was contributing to an increasingly elaborate body of international investment law. The proponents of the Study Group thus considered it timely to suggest the establishment of a study group to investigate whether the time was ripe for an attempt to formulate and summarize the main rules relating to investment law in a 'codification'type instrument. Their initial proposal made it very clear that the Study Group's mandate should not extend to an attempt to partially or exhaustively codify rules of investment law. Rather, the focus of the Group's work should be on the assessment of the ripeness of such an undertaking. Thus, the Study Group's mandate concentrates on the elaboration of a 'feasibility study'.

After the untimely death of Professor Wälde in late summer 2008, Professor Bjorklund agreed to serve as Co-Rapporteur of the Study Group. The Group was formally established in November 2008. It had working meetings in June 2009 in Vienna, in November 2009 in London, in August 2010 in The Hague and in March 2011 in Vienna.

At these meetings crucial decisions concerning the work and working methods of the Group were taken. In addition to the periodic reports due for ILA Conferences, the Group decided that it would work towards the publication of a book containing the contributions of the Group's members. The Group focused on identifying the main issues surrounding a potential 'codification' of investment law and investigating whether and in what form investment law may be 'codified'. The contributions in this book, which contains the major output of the Study Group's work, could lead to a recommendation that the ILA pursue the elaboration of an international soft law instrument on international investment.

The ILA has a long-standing tradition of formulating 'Rules', 'Recommended Practices', 'Draft Articles' and the like in an attempt to contribute to the codification and development of various fields of international law.

In the field of investment law, such a soft law instrument could provide a contemporary view of the state of the emerging and in several areas already settled jurisprudence of international investment law. Indeed, a significant contribution would be to identify those areas in which one can identify a jurisprudence constante. It could thereby serve tribunals, parties and counsel in helping to identify the current state of investment arbitral jurisprudence and scholarship (in the sense of Article 38 of the ICJ Statute). By objectively describing the current state of international investment law it could facilitate the identification of customary international law. Such an instrument could also assist governments in the negotiation and renegotiation of existing bilateral investment treaties 
where the trend is to incorporate (or react to) investment arbitral jurisprudence by adding much more detail to the hitherto quite openended treaty obligations. Finally it could, if a window of political opportunity emerged, provide an early model and drafting text for another attempt at a legally binding multilateral investment convention.

The Study Group's book is, however, also intended to analyse the potential disadvantages of soft law instruments. It is evident that in situations where there is no established case law a soft law instrument would leave a gap or would have to state a principle by endorsing an approach that had not earned consistent or near-universal support. In the case of conflicting approaches, choices made at the drafting stage might result in wording that would not necessarily be representative of any leading approach. Finally, a soft law instrument might have to be formulated so generally to be representative of all various approaches that it could not induce harmonization when specific questions have to be decided.

Furthermore, the variety of potential end-users described above could prove to be a challenge should the Study Group conclude that drafting a soft law instrument is feasible. A precise descriptive statement of existing law might be of most use to counsel and arbitrators, whereas a more prescriptive approach suggesting innovative practices might be more appropriately addressed to legislative bodies. In either case, a clear and objective assessment of purpose is essential to establish the credibility of the drafters and the reliability of the product.

The 'feasibility' study of the Study Group contained in this book is intended to address these issues head-on. For that purpose, a number of its members were asked to analyse previous experiences in other fields. This involves, among others, a discussion of soft codifications in the area of commercial law, addressing the scope of the relevant instruments (e.g. the specificity of INCOTERMS ${ }^{3}$ vs the generalized nature of the UNIDROIT Principles of International Commercial Contracts ${ }^{4}$ ), language problems that may arise in the course of such 'codification' exercises, as well as the difficulties involved when ascertaining whether there is true or merely apparent consensus. In commercial law, soft law instruments have been very successful in practice by leading to predictable results, in particular where they are sufficiently precise so that they can be interpreted without being influenced by the legal tradition of the interpreter.

\footnotetext{
3 ICC, Incoterms 2000 (ICC Pub 1999).

4 UNIDROIT Principles of International Commercial Contracts 2004, endorsed by the UN Commission on International Trade Law, UN Doc A/62/17 (Part I) (23 July 2007), 52-4.
} 
Similar experience in other fields like environmental law, as well as GATT/WTO law, is considered in this book. The latter field demonstrates that a fruitful approach need not be uniform, but could include binding treaties, such as the Antidumping ${ }^{5}$ and Subsidies ${ }^{6}$ Agreements, the Agreement on Technical Barriers to Trade, ${ }^{7}$ and the Agreement on the Application of Sanitary and Phytosanitary Measures, ${ }^{8}$ as well as the interactions of those treaties with non-binding standards set by various institutions, like the International Organization for Standardization (ISO). ${ }^{9}$

Finally, experiences taken from general public international law provide useful material to assess the feasibility of a 'codification' of investment law. In this context, the ILC codification efforts, including those on State responsibility, ${ }^{10}$ the iterative Law of the Sea conventions, ${ }^{11}$ State

5 Agreement on Implementation of Article VI of the General Agreement on Tariffs and Trade 1994 (Anti-dumping Agreement), 15 April 1994, entered into force 1 January 1995, Marrakesh Agreement Establishing the World Trade Organization, Annex 1A, 1868 UNTS 201.

Agreement on Subsidies and Countervailing Measures, 15 April 1994, entered into force 1 January 1995, Marrakesh Agreement Establishing the World Trade Organization, Annex 1A, 1869 UNTS 14.

7 Agreement on Technical Barriers to Trade, 15 April 1994, entered into force 1 January 1995, Marrakesh Agreement Establishing the World Trade Organization, Annex 1A, 1868 UNTS 120.

Agreement on the Application of Sanitary and Phytosanitary Measures, 15 April 1994, Marrakesh Agreement Establishing the World Trade Organization, Annex 1A, 1867 UNTS 493.

9 The Agreement on Technical Barriers to Trade encourages State Parties to comply with a Code of Good Practice; local governments, non-governmental and other standardizing bodies, including the ISO, can also accept the Code of Good Practice. This cooperative approach contributes to a uniformity of technical regulations that facilitates, rather than impedes, trade. The Agreement on the Application of Sanitary and Phytosanitary Measures encourages members to use international standards, guidelines and recommendations, such as those set out by the ISO.

10 In 2001, the Commission completed its second reading of the Draft Articles on the Responsibility of States for Internationally Wrongful Acts. The Commission adopted the text of the articles and submitted them to the General Assembly with the recommendation that it take note of the articles in a resolution and that it annex the articles to the resolution. The Commission further suggested that the General Assembly consider, at a later stage, convening an international conference with a view towards adopting a convention on the topic. Report of the Commission at its Fifty-third Session, UN Doc A/56/10 (2001), para 11.

11 The ILC's work on the Law of the Sea has resulted in several multilateral conventions regulating the law of the high seas, of the continental shelf, and of the 
succession, $^{12}$ and State immunity ${ }^{13}$ provide an interesting point of departure. At the same time scholarly attempts to offer broad annotated commentaries on core public international law topics, such as Judge Bruno Simma's UN Charter Commentary, ${ }^{14}$ or the Commentary on the Statute of the ICJ ${ }^{15}$ provide useful techniques for investment purposes.

Also former attempts to codify investment law, such as the OECD projects of the $1960 \mathrm{~s}^{16}$ and $1990 \mathrm{~s}^{17}$ and related projects, as well as different generations of BITs and other international investment agreements, may equally be viewed as representing forays into codification.

territorial seas and the contiguous zone. The Convention on the High Seas entered into force on 30 September 1962, while the second and current UN Convention on the Law of the Sea entered into force 16 November 1994. UN Convention on the Law of the Sea, 10 December 1982, 1833 UNTS 3. See also Convention on the High Seas, 29 April 1968, 450 UNTS 11; Convention on the Continental Shelf, 29 April 1958, 499 UNTS 311; Convention on the Territorial Sea and the Contiguous Zone, 29 April 1958, 516 UNTS 205.

12 The ILC initially considered succession in respect of treaties, succession in respect of rights and duties resulting from sources other than treaties, and succession in respect of membership in international organizations. The ILC set aside the latter topic and appointed a special rapporteur to explore the first two. The ILC has never acted on the topic, but has prepared several reports summarizing state practice: The succession of States in relation to membership in the United Nations, UN Doc A/CN.4/149 and Add. 1 (3 December 1962), 101 et seq.; Succession of States in relation to general multilateral treaties of which the SecretaryGeneral is the depositary, UN Doc A/CN.4/150 (10 December 1962), 106 et seq; Digest of decisions of international tribunals relating to State succession, UN Doc A/ CN.4/151 (3 December 1962), 131 et seq; Digest of decisions of national courts relating to succession of States and Governments, UN Doc A/CN.4/157 (18 April 1963), 95 et seq.

13 The ILC project on State Immunity has resulted in the adoption by the General Assembly of the United Nations Convention on Jurisdictional Immunities of States and Their Property, UN Doc A/RES/59/38 (16 December 2004). As of 29 May 2010 ten States had ratified the Convention but it had not yet entered into force.

B Simma, The Charter of the United Nations: A Commentary (Oxford University Press 1994).

15 A Zimmerman, C Tomuschat and K Oellers-Frahm (eds), The Statute of the International Court of Justice: A Commentary (Oxford University Press 2006).

16 The OECD Council published a Draft Convention on the Protection of Foreign Property in 1967, but the draft was never formally adopted. Resolution of the OECD Council, 12 October 1967, 7 ILM 117.

17 From 1995 to 1998 the OECD hosted a series of negotiations designed to produce a multilateral agreement on investment (MAI). The negotiating group produced a draft text, but the negotiations stalled. For a draft text, see The Multilateral Agreement on Investment: Draft Consolidated Text, DAFFE/ MAI(98)7/REV1 (22 April 1998). 
Special attention is given to different forms of soft law instruments and their advantages and disadvantages. National samples, like the US Restatements, ${ }^{18}$ Dicey and Morris, ${ }^{19}$ etc., as well as international ones, like the UNIDROIT Principles ${ }^{20}$ the OECD Guidelines for Multinational Enterprises, ${ }^{21}$ ILA resolutions, ${ }^{22}$ Institut de Droit International resolutions, ${ }^{23}$ OECD Model Tax treaties, ${ }^{24}$ the Ruggie-commissioned study on stabilization clauses, ${ }^{25}$ the Association of International Petroleum Negotiators standardized oil and gas contracts, ${ }^{26}$ Energy Charter Treaty Secretariat model agreements, ${ }^{27}$ etc., are scrutinized with a view to their adaptability for investment law purposes.

A central question to be clarified for the purpose of the formulation of a soft law instrument is the issue of the breadth of the investment law that might be subject to soft law instruments or other forms of 'codification'; in other words, whether a 'codification' should comprise only core standards or also include broader 'investment and ...' issues, such as human rights protections and environmental norms.

18 For a complete list of US Restatements of the Law, see <http:// tinyurl.com/24vm7rr $>$. A current Restatement project of interest for the Study Group project is the proposed Restatement on the US Law of International Commercial Arbitration. Chapter 6 of that Restatement will address investor-state dispute settlement as it interacts with US courts. Maxwell 2006).

L Collins, Dicey, Morris and Collins on the Conflict of Laws (Sweet \&

20 UNIDROIT Principles of International Commercial Contracts 2004, endorsed by the UN Commission on International Trade Law, UN Doc A/62/17 (Part I) (23 July 2007) 52-4.

21 OECD, OECD Guidelines for Multinational Enterprises, DAFFE/IME/ WPG(2000)15/FINAL (31 October 2001).

22 Reports of all ILA Conferences, including the text of the Resolutions adopted by the Association, are available on HeinOnline.

23 A chronological index of the resolutions adopted by the Institut de Droit

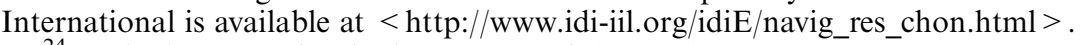

24 The latest version is the Articles of the Model Convention with Respect to Taxes on Income and Capital (17 July 2008), available at <http://www.oecd.org/ dataoecd/43/57/42219418.pdf $>$.

25 Andrea Shemberg, Stabilization Clauses and Human Rights: A research project conducted for IFC and the United Nations Special Representative to the Secretary General on Business and Human Rights (11 March 2008), available at $<$ http://tinyurl.com/2excemo $>$.

26 For a list of model contracts available from the AIPN, see $<$ http:// www.aipn.org/modelagreements $>$.

27 Energy Charter Secretariat, Model Intergovernmental and Host Government Agreements for Cross-Border Pipelines (2nd edn, Energy Charter Secretariat 2007). 
Equally important is a clarification of the sources of investment law, the extent to which there is a hierarchy of sources, fragmentation issues resulting from the problem of inconsistent treaties, the use of ad hoc arbitral bodies, and the lack of any kind of system of precedent or topdown control mechanism to impose consistency on tribunal decisionmaking, and the relationship between investment law and other bodies of international law.

This study investigates also various techniques and the practical problems of 'codification'. The fact that there is an exponentially growing law and that there are increasing instances of inconsistencies, etc., makes it more difficult to ascertain commonalities of approach. The present book thus identifies areas where there is homogeneous case law and where there are divergent approaches by individual tribunals, including the debate over the most-favoured-nation clause, the 'umbrella' clause, and the notion of investment. It also attempts to identify applicable principles in those situations in order to achieve predictability.

Of significant interest is the role of arbitrators in whatever 'codification' process is under way in the area of investment law. The identification of sources from which tribunals should draw in coming to their conclusions and the identification of sources that ought properly to provide the basis for a codification will pose serious problems.

Two specific studies will test sample codification approaches. In particular, the non-discrimination standard of in expropriation and mostfavoured-nation (MFN) treatment lend themselves to further exploration.

A chapter on MFN will try to give an overview on the practice of tribunals in this field and derive answers as to whether it seems likely that a common understanding on the scope of the MFN clause could be agreed upon for use in a multilateral system and, if so, what it should be. The main types of MFN clauses, currently found in the bilateral investment treaties (BITs) of major players in this field and the topical arbitration awards, will be analysed.

Finally, a chapter will deal with expropriation, a topic that has already formed the basis for a substantial amount of case-law based on customary international law principles and on treaty provisions. By way of a 'sample codification' a specific aspect of expropriation - the legality requirement of non-discrimination - will be addressed. In this field, the practice of international tribunals strongly supports the assumption that nondiscrimination is a requirement for the legality of an expropriation both under customary international law as well as under specifically applicable IIAs. While tribunals tend to qualify politically motivated or other egregious forms of discrimination as unlawful, they do apply a more nuanced approach to expropriations which affect only some foreigners if 
such discrimination may be the result of legitimate government policies. These fairly uniform interpretations may lend themselves to an interpretation apt for codification.

One of the threshold questions we needed to consider was what, at least in broad terms, we mean by soft law for the purposes of this study. While we did not find it necessary to adopt, as a Group, a specific definition of soft law or its role in international investment law, we have chosen to devote a short early chapter to provide an overview of the large body of literature on the subject. The purpose of this chapter is to inform the rest of the book rather than to limit the scope of each contribution - indeed, each contributor wrote his or her chapter without reference to this introductory chapter or any constraint imposed by a Group-level understanding of what exactly we mean by soft law.

This book containing the papers forming the foundation of the ILA Study Group's project is organized as follows. After this introductory chapter, three chapters discuss different facets of 'soft law'. Chapter 2, written by Moshe Hirsch, introduces the primary sources of international law and describes their relationship with soft law. Chapter 3, authored by Melaku Desta, addresses soft law generally, while Chapter 4, written by Andrea Bjorklund, examines the factors that lead soft law instruments to be successful and critically appraises the advantages and disadvantages of various instruments with an eye towards their efficacy in the field of international investment law.

The following three chapters are studies of the ways that soft law has been used in various fields. Chapter 5, written by Kate Miles, examines the important influence soft law instruments have had in the field of international environmental law. In Chapter 6 Giuditta Cordero-Moss assesses the effectiveness of various soft law manifestations in international commercial law. In Chapter 7, Melaku Desta turns to the innovative ways in which the WTO Agreements have encouraged the mingling of hard and soft law.

The next three chapters look more specifically at international law's ripeness for codification. In Chapter 8, Christian Tietje and Emily Sipiorski explore the development of international investment treaties and examine the common strands that unify the current generation of investment treaties. Chapter 9, written by Andreas Ziegler, assesses whether the most-favoured-nation obligation is ripe for codification or multilateralization. In Chapter 10, August Reinisch examines particularly the 'legality' requirement in the standard of expropriation and attempts a sample codification. Finally, a concluding chapter written by August Reinisch and Andrea Bjorklund addresses the ripeness of international investment law for concretization in a soft law instrument. 